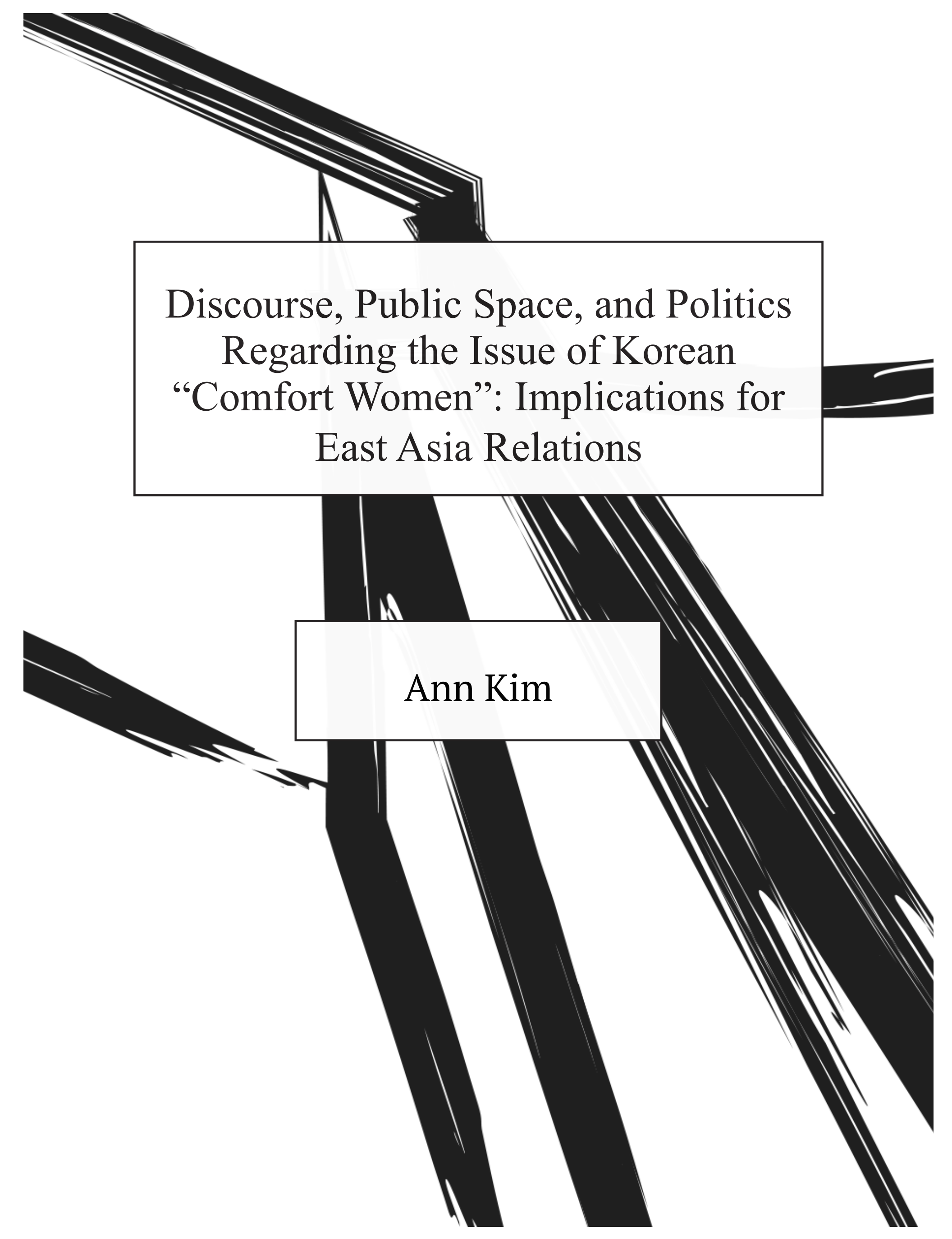





\title{
Discourse, Public Space, and Politics Regarding the Issue of Korean "Comfort Women": Implications for East Asia Relations
}

Ann Kim

\begin{abstract}
The issue of "comfort women," sex slaves utilized by the Japanese army during World War II, is treated in this paper as a collective memory in the consciousness of South Koreans. This serves as the underlying basis for increased present tensions between the governments of South Korea and Japan. To understand the complexity of these painful experiences as a collective memory requires a discussion on the impact of colonization as well as on contemporary problems regarding a whitewashing of history and the utilization of public space for the memorialization of these women. The result of these factors is the exacerbation of tension between the South Korean and Japanese governments, mainly due to a widely perceived belief within South Korea regarding the Japanese government's reluctance to engage in transparent discussions regarding history. This tension will likely impact cooperation between the two countries on issues in East Asia. The paper not only seeks to examine Japan-South Korea relations, but to emphasize the importance of focusing the narrative on the individual women who were subjected to such atrocities.
\end{abstract}

Keywords: Comfort Women, Public Space, Memorialization, Collective Memory, Japanese-Korean Relations 


\section{Introduction}

For South Korea, "comfort women"-a euphemistic term referring to nearly 200,000 women who were sex slaves for the Japanese military during World War II-have become a reminder of brutal Japanese colonial rule. They have subsequently become a source of tension in current politics, which has been characterized by an emphasis on security considerations. While much of the discourse centers around the women's stories, there is also a broader underlying intersection between topics of colonialism, power, women, and sex. While Korea was under Japanese colonial rule from 1910 to 1945 , the political situation of a subjugated Korea and dominant Japan allowed the Japanese empire to kidnap young women or coerce them into military brothels by lying about the nature of the work promised. The issue surrounding comfort women becomes a point of pain for Koreans angered by the remnants of colonial rule and brings into consideration the role of power dynamics and gender hierarchies.

In order to follow the discourse surrounding this contentious topic, it is necessary to examine the term "comfort women". For the purposes of clarity, this term is used in this paper as it is the most widely used, though it is a largely euphemized one. It is a translation from the Japanese word ianfu, which means "army prostitute."[1] However, this term in the Japanese language is problematic, as it suggests a woman's sole aim was to provide service for men. It also suggests the notion that each woman was a prostitute, or consciously chose to trade sexual acts for payment. This is not an accurate representation of the situation for many of these women, as several separate survivors highlight how they were never allowed to leave the house, were regulated to one meal a day, and how few of these women saw monetary payment. [2] A phrase that better encompasses the reality of their situation is "sex slave", yet this is largely problematic as well, for it reduces the individual solely to the act that they were forced to carry out. Today within South Korea, they are referred to as weeanbu, another word for "comfort women" or sexual slaves - the term's connotations clearly allude to one who was held against their will. Some South Koreans today also simply use the 
word halmoni in reference to these survivors, a universal term for "grandmother" which carries undertones of affection and respect.

It is important to make the distinction between an apology South Korea deems adequate, which would be a full acceptance of responsibility for the forced enslavement of these women. In reality, the widely held view had been that the Japanese government's attempts at apologies are disingenuous attempts at reconciliation, while the Japanese government contends their efforts fulfill moral responsibilities. However, because Japan's past apologies have not met the expectations of South Koreans nor a number of the surviving comfort women, this contentious subject serves as a barrier to collaboration on present issues. Despite the history of Japan's forcing of Korean women to become comfort women-which has created a collective memory that directly affects these women-Japan shows reluctance to address its lasting emotional impact on Korea.

\section{Historical and Social Context: War and Colonialism}

The impact of colonization is critical in understanding the power dynamic that was on display between an imperialist country and its colonies. The period from 1932 to 1945, the years during which comfort women were most prevalent in Japan, was characterized by colonialism and World War II. Korea was a colony of Japan's from 1910 to 1945, meaning that not only was it a conquered territory, but also that the relationship between peoples was marked at times by brutal interactions. During this period, the Japanese placed restrictions on the press, the Korean language, and education, while many citizens were subjected to forced labor and brutal cross-cultural encounters. This colonization came in the forms of state and military control, as well as development in the form of economic conglomerates and focus heavy industries and infrastructure.

The strong emotions towards colonial oppressors seem intensified as colonialism benefited Korea in industrializing and hastening its modernization as a state. However, at its core, colonialism denotes a clear power imbalance between the colonizer and the colonized - therefore, this is an unnecessary 
justification for a brutal regime. Cumings explores the difficultly of reconciling Japan's colonial impact on Korea. He notes that the complex relationship between the two explains:

[W]hy one Korea indulges in a myth that everyone resisted and the other in a myth that no one collaborated... Korea's march to modernity coincided with imperial aggression and colonial exploitation: this is hard enough for any people to take. But aggression and exploitation also coincided with fairly remarkable development and a learning-by-doing experience of how education, military, polity, and economy can be modernized. Thus the Japanese set up a love-hate conflict that has gnawed at the Korean national identity ever since. [4]

This narrative Cumings constructs explains the persistent view held by some South Koreans that no individual was complicit during the time of colonization, and the refusal to believe that the impact of colonization brought about any sort of benefit. This is not to say that Japan's brutal colonial conquest was justified, but rather to emphasize the need to evaluate history from multiple narratives and less polarizing perspectives. Understanding the painful and complex history of colonialism, the effects of which are still felt today, is necessary to better contextualize the experiences of the comfort women.

\section{Survivor Testimony and Collective Memory}

The personal stories of survivors who chose to share their experiences have become embedded within South Koreans' collective consciousness as passed-down memories that transcend generations. Although many of these women were from China, Korea, Taiwan, the Philippines, and even the Netherlands and Australia (countries that fell under Japan's sphere of influence during WWII), this paper will only focus on the experiences of the Korean comfort women, who comprised an estimated 50-75\% 
of the ethnic makeup of these victims.[5] After the war, the shame many of these women felt due to the structure of Korean society, an emphasis placed on virginity and a tradition of stigma around sex, meant that their sufferings went unheard for almost 50 years after the war. In a gendered, hierarchical society such as South Korea's, it is not surprising that it took so many years for the first story to come into public awareness. In 1991, Kim Hak-Soon was the first woman to step forward and share her story. Speaking about her experiences in Dae Sil Kim-Gibson's documentary Silence Broken: Korean Comfort Women, she states:

The war ended in 1945. For half a century, no words from Japan. In the newspapers and TV news, Japan kept denying it. 'Koreans did it to make money.' Would they allow Koreans to make money? Day and night, you say that it never happened. But here I am, a living witness. So I stepped forward in 1991. In the evening of August 14 , we called the press. That's how the silence was broken. [6]

Since then, more than 200 women have come forward to speak of their experiences. Today, there are only 35 survivors in South Korea, all over the age of 90.[7] Many live within the "House of Sharing", a nursing home run by Buddhist organizations dedicated to publicizing the truth about comfort women as well as providing a space for survivors who participate in art therapy and share their experiences.

Much of the written and oral testimony given by these women exhibits feelings of anger, disgust, or pain, and nearly all allude to symptoms of Post-Traumatic Stress Disorder (PTSD). Most speak of contracting venereal diseases such as syphilis and combatting it through forced drug injections of "\#606" instead of proper medical care or rest. Many of the women from rural areas were told that they would be doing work as maids or factory workers, as a way to provide an income to their families. Some were commanded to go without an explanation or because their relatives were threatened. The common thread among all 
these stories is that no individual knew their fate before being taken to a "comfort station", usually located in China or Japan. One individual spoke about having to "work" from "eight in the morning until ten at night."[8] In the documentary Silence Broken: Korean Comfort Woman, Cheung Seo Woon recalls: "the soldiers stood in line. Sometimes... I believe more than hundred men a day."[9] Many comfort women witnessed beatings, forced abortions or executions of those too sick to carry on. Many of these women, as young as 14 or 15, talk about the initial shock, as nearly all were virgins, and the pervasive feeling of "wanting to die... right there and then."[10] One individual commented that "this rage is still so strong that I will not ever be able to rest in peace before the Japanese government apologizes to me personally for their crime committed against me."[11] The intensity and pain of these memories are so strong that the experiences of these comfort women fit into a "collective memory", where the emotions transcend generations and explain the existing antagonism. According to historian Arthur Neal's characterization of collective memory:

The enduring effects of a trauma in the memories of an individual resemble the enduring effects of a national trauma in collective consciousness. Dismissing or ignoring the traumatic experience is not a reasonable option. The conditions surrounding a trauma are played and replayed in consciousness through an attempt to extract some sense of coherence from a meaningless experience. When the event is dismissed from consciousness, it resurfaces in feelings of anxiety and despair. Just as the rape victim becomes permanently changed as a result of the trauma, the nation becomes permanently changed as a result of trauma in the social realm. [12]

In his words, the personal memories of survivors become interwoven into the collective memory of a nation, with the trauma ingrained in the nation's history. The experiences of 
Korean comfort women follows this trajectory, as these individual memories have not only become part of Korean and Japanese political discourse but also have become incorporated in every Korean's consciousness.

\section{Memorialization and Public Space}

The anger that is still vividly felt today has contributed to ongoing public protests and the creation of statues that emphasize the role of politics and the deeper underlying cultural issues regarding the conflict over these statues in the public space. The placement of these statues in front of the Japanese embassy in Seoul is highly political. For example, there is a seated bronze figure that memorializes and raises awareness about the issue of comfort women. The statue was unveiled in 2011 on the 1,000th day of the "Wednesday Demonstrations", protests that have occurred every Wednesday in front of the Japanese embassy since 1992, prompting al-Jazeera to call it "the longest running protest in the world."'[13] In response to the creation of this statue, the Japanese government recalled its envoy to South Korea, claiming that the protests and memorials presented one-sided views.

The statue was created by a Korean couple, Kim SeoKyong and Kim Eun-Sung, who spoke of the guilt and rage they felt, which ultimately propelled the creation of the statue. [14] The bronze girl sits defiantly in traditional hanbok, with her hair chopped haggardly. This illustrates the detail that many Japanese soldiers forcibly cut the braids of young women's hair, a symbol of virginity. She looks young but holds a defiant gaze; the combination of these two characteristics seem to highlight a simultaneous vulnerability and resilience. To her right is an empty chair, symbolizing those who died of venereal diseases, committed suicide, or were murdered by the Japanese to conceal their atrocities following Emperor Hirohito's surrender at the end of World War II. Most of the public's interactions with the figure are respectful-flowers are laid at her feet, and often a knit scarf or hat is placed on her as if to protect her from the cold. Surviving comfort women who visit the statue sit on the bronze chair to her right, and place their hand on the statue's, as if to console each 
other.

A similar figure has appeared on a number of Seoul's buses. Commissioned by the Dong-A Transit company, there are five buses that displayed one of these statues until the end of September 2017.[15] In a bustling metropolitan city that relies heavily on public transportation, the presence of one of these memorials in a transitory public space not only ensures that a wide range of people see it and forces passengers to confront this defiant figure, and therefore the issue of comfort women as soon as they board. This transformation of the social space into one that conveys broader political and cultural meaning occurs not only with the mere placement of the statue on the bus, but with individual reactions to the figure and the feelings or memories it evokes. Overall, the numerous comfort women statues serve a unique function beyond memorialization-to evoke immediate reactions of compassion and immense grief towards the experiences of the women and create a strong, visceral rage towards the Japanese and the underlying history of colonialism.

\section{Discourse in Politics and Historical Accounts}

The use of public space to create heightened awareness of Korean comfort women has increased discourse regarding these incredibly sensitive experiences and how to reconcile them. Japanese politicians' varying interpretations of historical accounts have contributed to this discourse and may have influenced attitudes toward reparations. For example, Nariaki Nakayama, a prominent Japanese politician within the Liberal Democratic Party declared, "we need to raise our voices and tell the world that [females] were not forcibly taken away."[16] While his view does not represent the majority of Japanese officials, it is still disturbing and trivializes or denies the experiences of thousands of women. Even certain academics possess a similar view such as Kumagai Naoko, a Japanese historian who researches comfort women extensively. He argues that "sex slaves" is a term that does not encompass all perspectives or experiences, and cites archival evidence that some of these women were paid.[17] Even if this were true, it does not detract from the fact that the majority of 
the women were never compensated, and that they were forcibly taken or lied to about the nature of the work. It invalidates the stories of the majority of the individuals for whom this was not the case. For example, Ms. K, an anonymous survivor, recounts, "our supervisors took the money, saying they would save it for us. In any case, I never received a penny from them."[18]

These varying historical interpretations not only influence broad views held by individual government members, but also the official stances of the government as a whole. The Japanese Foreign Ministry, which has issued a number of statements since 1992, is careful to omit harsh or antagonizing language. Even the Kono statement of 1993, largely understood as the government's first acknowledgment of the atrocity of the issue, is not entirely forthcoming. What Jennifer Lind calls Japan's "History Problem", meaning the issue of whitewashing historical events, is prevalent even in government statements and publications. Nowhere in the Kono statement is there any explicit mention of rape or sexual slavery. Instead it uses words such as "coercion" and "coaxing." The language itself is technical and suggests distance and nonengagement. By contrast, the language of many of the survivors is direct and explicit.

However, it must be emphasized that this concerning view is not held by most Japanese historians or citizens. Many of them continue to call for their government to adhere to a more transparent approach in addressing the issue of comfort women. For example, the Japanese historian Yoshiaki Yoshimi worked tirelessly to expose Japan's concealment of wartime atrocities in pursuit of portraying accurate historical facts.[19] In addition, over 400 Japanese scholars have penned and signed the "Open Letter in Support of Historians in Japan", which urges Prime Minister Shinzo Abe to reconsider typical historical narratives within Japan.[20] Conversely, South Korean scholars have also de-emphasized the narrative of forced kidnappings and brutal rape as the sole account of events. South Korean professor Park Yu-Ha was accused of defamation and fined for her book Comfort Women of the Empire, which outlined the fact that South Korean individuals, not solely the Japanese, were occasionally involved in the kidnapping of some of the women.[21] The South 
Korean government and public's swift response to this particular historian (as many branded her a traitor) is also alarming. It displays a commitment to a single version of history closed off to alternative historical accounts and any possible changes. The ongoing controversies regarding what is the accurate portrayal of events point to a larger problem in dealing with emotional histories - that challenging the status quo and long-held beliefs is both incredibly painful and difficult to overcome.

\section{The Continuing Issue of Comfort Women in Present Day Interactions}

The outrage has resurfaced after the release of a 2015 agreement between Japan and South Korea, which was largely intended to resolve the issue by using $\$ 8.3$ million to contribute to a foundation for the survivors in exchange for the removal of these statues around South Korea.[22] However, the desire for a direct apology from Japan and the issue of whether or not survivors should accept payment from a foundation unaffiliated with the Japanese government became politicized. According to The New York Times, "critics inside and outside Japan complained about the Japanese government's decision to set up the fund as a private one, making clear that the 'atonement' payments came from citizens. They saw this as another tortured attempt by Tokyo to avoid taking full responsibility for one of the ugliest aspects of the war.’'23] Survivor Kim Soo-Ja stated:

It is more important to get a sincere apology than simply to get a monetary compensation. I am not merchandise that can be traded for money. Even if they give me Japan as a whole, they cannot compensate for my lifelong suffering. I will never accept money from the Asian Women's Fund. The Japanese government should make a sincere apology and directly compensate me [24]

According to a poll, nearly $75 \%$ of Koreans did not think that the Japanese government's statement was sufficient.[25] Many 
of the interviews with survivors reflect this view; they expected a full acceptance of responsibility and a formal apology from Japan. Instead, South Korean activists and survivors saw the statement as an attempt by the government to silence the comfort women, to continue to evade assuming responsibility, and to limit the activists' activities. Due to the fact that many comfort women survivors and activist groups saw the agreement as an insincere attempt at an apology, the 2015 agreement negotiations fell through. It must be emphasized that although the sufferings of the survivors can never be truly atoned for, an accurate and objective historical account as well as transparent discourse is the necessary first step before attempting reparations.

Given the symbolic power of memorialization and structures in public space, the question becomes one of Japan's cooperation in maintaining the statues and therefore a broader commitment to historical accuracy. To signal its willingness to engage with multiple historical perspectives and the acknowledgment of the past, Japan must refrain from calling for the destruction of these monuments due to their historical and symbolic significance. Ultimately, the testimony of comfort women survivors and the perpetual presence of memorial statues reveal the tension between discourse and public space. It is especially important to recognize that cooperation between Korea and Japan is necessary to handle the security situation in East Asia. The politicization of the issue, exemplified by Japan's refusal to issue individual apologies, reveals the lasting effects of colonialism on the relationship between Korea and Japanone that is unlikely to improve without a sincere incorporation of historical fact in the dialogue to acknowledge survivors. 


\section{Notes:}

1 Kirsten Orreill,"Who are the Ianfu (Comfort Women)?" New Voices, no. 2 (December 2008): 129.

2 Sangmie Choi Schellstede, Comfort Women Speak: Testimony by Sex Slaves of the Japanese Military, edited by Soon Mi Yu. (New York: Holmes \& Meier, 2000), 8.

3 Bruce Cumings, "The Legacy of Japanese Colonialism in Korea," in The Japanese Colonial Empire, 1895-1945, ed. Ramon H. Myers and Mark R. Peattie (Princeton: Princeton University Press, 1987), 218.

4 "Number of Comfort Stations and Comfort Women." Number of Comfort Stations and Comfort Women. http://www.awf. or.jp/e1/facts-07.html.

5 Silence Broken: Korean Comfort Woman. Produced by Charles Burnett and Dai Sil Kim-Gibson. Directed by Dai Sil Kim-Gibson. (Seoul, 2000).

6 Bemma, Adam. "South Korea: World's longest protest over comfortwomen." South Korea News |AlJazeera. September 07, 2017. http://www.aljazeera.com/news/2017/09/south-koreaworld-longest-protest-comfort-women-170908024721239. html.

7 Sangmie Choi Schellstede, Comfort Women Speak.

8 Silence Broken: Korean Comfort Woman. Produced by Charles Burnett and Dai Sil Kim-Gibson. Directed by Dai Sil Kim-Gibson. (Seoul, 2000).

9 Schellstede, Sangmie Choi. 2000. Comfort Women Speak, 30.

10 Ibid., 92. 
11 Arthur G. Neal, National Trauma and Collective Memory: Major Events in the American Century. (Armonk, N.Y: Sharpe, 1998).

12 Adam Bemma, "South Korea: World's longest protest over comfort women." South Korea News |AlJazeera. September 07, 2017. http://www.aljazeera.com/news/2017/09/south-koreaworld-longest-protest-comfort-women-170908024721239. html.

13 Herald, "Comfort women' statues resonate with Koreans." The Korea Herald. March 03, 2016. http://www.koreaherald. com/view.php?ud=20160303000844.

14 Justin McCurry. "Buses in Seoul Install 'Comfort Women' Statues to Honour Former Sex Slaves." The Guardian. August 16, 2017. https://www.theguardian.com/cities/2017/aug/16/ buses-seoul-comfort-women-statues-korea-japan.

15 "Forcibly Recruited Korean Sex Slaves a Myth: Lawmaker." The Japan Times. https://www.japantimes. co.jp/news/2013/06/08/national/politics-diplomacy/femaleswerent-forced-into-wartime-military-brothels-nippon-ishinlawmaker/\#.WiV1IhNSySN.

16 Kumagai Naoko and David Noble. The Comfort Women: Historical, Political, Legal and Moral Perspectives. (Tokyo: International House of Japan, 2016)

17 Sangmie Choi Schellstede. 2000. Comfort Women Speak, 104.

18 Norimitsu Onishi, "In Japan, a Historian Stands by Proof of Wartime Sex Slavery." The New York Times. March 31, 2007. https://www.nytimes.com/2007/03/31/world/asia/31 yoshimi. html.

19 "Open Letter in Support of Historians in Japan." Letter. 2015, May 5, 2015. https://networks.h-net.org/system/files/ 
contributed-files/japan-scholars-statement-2015.5.4-eng_0. pdf.

20 'Professor Who Wrote of Korean 'Comfort Women' Wins Defamation Case." The New York Times. December 22, 2017. https://www.nytimes.com/2017/01/25/world/asia/koreancomfort-women-park-yu-ha-japan.html.

21 Jun Kwanwoo and Alexander Martin, "Japan, South Korea Agree to Aid for 'Comfort Women,"' The Wall Street Journal. December 28, 2015. https://www.wsj.com/articles/japansouth-korea-reach-comfort-women-agreement-1451286347.

22 Norimitsu Onishi, “Japan's 'Atonement' to Former Sex Slaves Stirs Anger." The New York Times. April 24, 2007. http:// www.nytimes.com/2007/04/25/world/asia/25japan.html.

23 Pyong Gap Min. “Korean 'Comfort Women': The Intersection of Colonial Power, Gender, and Class," in Gender \& Society 17, no. 6 (2003): 946.

24 Cetusnews, "17.07.27 Survey: $75 \%$ of S. Koreans think 'comfort women' issue unresolved," Cetusnews, July 27, 2017. http://www.cetusnews.com/life/Survey--75\%25-of-S-Koreans-think-\%E2\%80\%98comfort-women \%E2\%80\%99issue-unresolved.BJX9fiNvIZ.html.

\section{References:}

Bemma,Adam. "South Korea: World's longest protest over comfort women.” South Korea News|Al Jazeera. September 07, 2017. http:/www.aljazeera.com/news/2017/09/south-korea-worldlongest-protest-comfort-woen-17008024721239.html.

Cetusnews. "17.07.27 Survey: 75\% of S. Koreans think "comfort women' issue unresolved." Cetusnews. July 27, 2017. http:// 
www.cetusnews.com/life/Survey--75\%25-of-S--Koreansthink-\%E2\%80\%98comort-woen \%E2\%80\%99-issueunresolved.BJX9fiNvIZ.html.

"Forcibly recruited Korean sex slaves a myth: lawmaker." The Japan Times. https://www.japantimes.co.jp/news/2013/06/08/ national/politics-diplomacy/females-wernt-forcd-intowartime-military-brothels-nippon-ishin-lawmaker/\#. WiV1IhNSySN.

Herald. "Comfort women' statues resonate with Koreans." The Korea Herald. March 03, 2016. http://www.koreaherald.com/ view.php?ud=20160303000844.

Jun, Kwanwoo, and Martin, Alexander. "Japan, South Korea Agree to Aid for 'Comfort Women'." The Wall Street Journal. December 28, 2015. https://www.wsj.com/articles/japansouth-korea-reach-comfort-women-agreement-145186347.

Kumagai, Naoko, and Noble, David. The Comfort Women: Historical, Political, Legal and Moral Perspectives. Tokyo: International House of Japan, 2016.

Onishi, Norimitsu. "Japan's 'Atonement' to Former Sex Slaves Stirs Anger." The New York Times. April 24, 2007. http:// www.nytimes.com/2007/04/25/world/asia/25japan.html.

Orreill, Kirsten. "Who are the Ianfu (Comfort Women)?" New Voices, no.2 (December 2008): 128-52.

McCurry, Justin. "Buses in Seoul install 'comfort women' statues to honour former sex slaves." The Guardian. August 16, 2017.

Neal, Arthur G. National Trauma and Collective Memory: Major Events in the American Century. Armonk, N.Y: Sharpe, 1998.

Min, Pyong Gap. “Korean 'Comfort Women': The Intersection of Colonial Power, Gender, and Class." Gender \& Society 17, 
no. 6 (2003): 946.

"Number of Comfort Stations and Comfort Women." Number of Comfort Stations and Comfort Women. http://www.awf.or.jp/ e1/facts-07.html.

Schellstede, Sangmie Choi. 2000. Comfort Women Speak: Testimony by Sex Slaves of the Japanese Military. Edited by Soon Mi Yu. New York, NY: Holmes \& Meier.

Silence Broken: Korean Comfort Woman. Produced by Charles Burnett and Dai Sil Kim-Gibson. Directed by Dai Sil KimGibson. By Donald Sur.

Acknowledgements: The author would like to thank Dr. Roxanne Varzi, Associate Professor of Anthropology and Film \& Media Studies at the University of California, Irvine, for her assistance with this project. 
